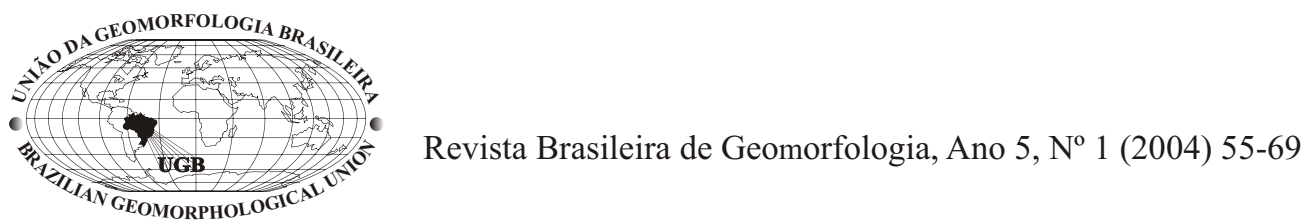

\title{
O Papel da Denudação Geoquímica no Processo de Erosão Diferencial no Quadrilátero Ferrífero/MG
}

\author{
The Hole of Chemical Denudation on Differential Erosion Processes in Quadrilátero \\ Ferrífero/MG
}

\section{André Augusto Rodrigues Salgado ${ }^{1}$, Fabrice Colin ${ }^{2}$, Hermínio Arias Nalini Jr. ${ }^{3}$, Régis Braucher ${ }^{4}$, Angélica Fortes Drummond Chicarino Varajão ${ }^{5}$ e César Augusto Chicarino Varajão ${ }^{5}$}

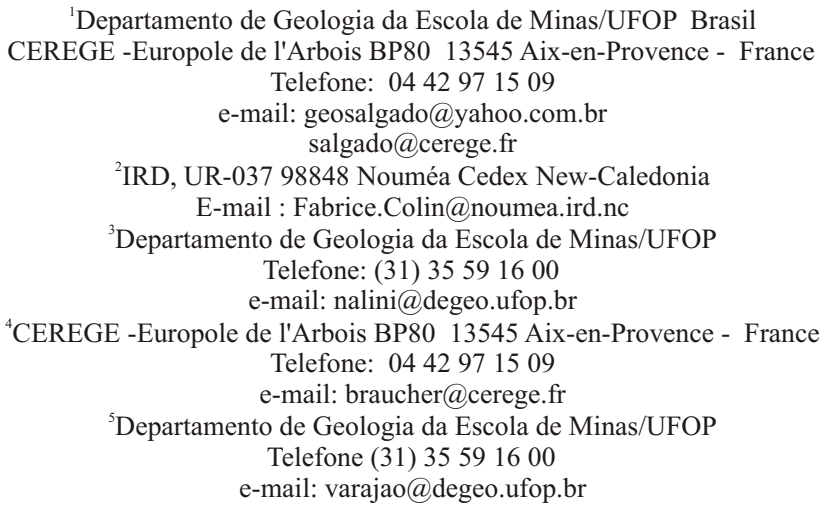

\begin{abstract}
Resumo
O presente trabalho investiga a contribuição da denudação geoquímica nos processos erosivos diferenciais do Quadrilátero Ferrífero/MG, área de relevante interesse geomorfológico por possuir, em seu modelado, importantes marcas desse tipo de processo. A fim de cumprir este objetivo foram utilizadas análises físico-químicas e químicas de águas superficiais coletadas em 18 (dezoito) pontos de monitoramento, localizados em quatro sub-bacias hidrográficas que drenam a área de estudo. Aárea em questão possui clima tropical semi-úmido com estações seca (inverno) e úmida (verão) bem delimitadas. A coleta das amostras de água foi realizada nestes dois períodos distintos. Os parâmetros analisados foram: $\mathrm{pH}$, sólidos totais dissolvidos (TDS), sílica, ferro, alumínio, sódio, cálcio, magnésio, manganês e potássio. Os resultados demonstraram que a denudação geoquímica é um dos fatores responsáveis pela erosão diferencial, uma vez que é possível verificar a existência de três comportamentos denudacionais geoquímicos distintos: (i) elevadas taxas de denudação geoquímica nas áreas moldadas sobre rochas carbonáticas; (ii) taxas médias de denudação geoquímica nas áreas modeladas sobre granitos, gnaisses, xistos e filitos e; (iii) baixas taxas de denudação geoquímica nas áreas mais elevadas (quartzitos e itabiritos) em relação às depressões adjacentes (xistos, filitos, granitos e gnaisses). Tal fato comprova para a área investigada que as águas fluviais regionais são capazes de marcar a assinatura geoquímica dos litotipos que drenam. Foi possível ainda concluir que, além dos litotipos, as áreas das bacias hidrográficas e as altitudes das mesmas em relação ao nível de base regional constituem fatores que também interferem na intensidade da denudação geoquímica.
\end{abstract}

Palavras -chave: denudação geoquímica diferencial, evolução do relevo, Quadrilátero Ferrífero.

\begin{abstract}
This work investigates the contribution of the chemical denudation to differential erosive processes in the Quadrilátero Ferrífero (State of Minas Gerais, Brazil). This is an area of relevant geomorphologic interest because the record of this type of process is well-preserved in the landscape. Semi-humid tropical climatic conditions predominate in the area, with a well-defined dry season in winter and a humid season in summer. Superficial water samples were collected in both seasons at 18 monitoring points located in four hydrographic sub-basins. The
\end{abstract}


parameters analyzed were: $\mathrm{pH}$, total dissolved solids (TDS), silica, iron, aluminum, sodium, calcium, magnesium, manganese and potassium. The resulting data show that the geochemical denudation is one of the factors responsible for the differential erosion, once three distinct behaviors of geochemical denudation were identified: (i) high geochemical denudation rates in the areas developed on carbonatic rocks; (ii) medium geochemical denudation rates in the areas developed on granites, gneisses, schists and phyllites, and (iii) low geochemical denudation rates in the areas developed on quartzites and itabirites, which are topographically higher than the adjacent rocks (schists, phyllites, granites and gneisses). These results show that the regional fluvial waters are able to mark the geochemical signature of the rock types being drained. One can also conclude that, besides the rock types, the hydrographic basin and its altitude in relation to the regional base level are factors that interfere in the geochemical denudation intensity.

Key words: differential chemical denudation, relief evolution, Quadrilátero Ferrífero.

\section{Introdução}

O Quadrilátero Ferrífero possui cerca de $7.200 \mathrm{~km}^{2}$ e localiza-se no interior do Estado de Minas Gerais, junto à borda sul do Craton do São Francisco (Almeida, 1977). Está situado em região de clima tropical semi-úmido, possuindo duas estações climáticas bem definidas: (i) verões úmidos e ; (ii) invernos secos. Trata-se de uma das mais importantes províncias minerais do Brasil. Além disso, possui significativo interesse geomorfológico devido à sua complexa estrutura geológica. A estratigrafia da região foi resumida por Alkmim \& Marshak (1998) em: (i) embasamento cristalino, de idade arqueana, composto por granitos, gnaisses e migmatitos; (ii) Supergrupo Rio das Velhas, de idade arqueana, composto basicamente por quartzitos, xistos e filitos que constituem uma sequência tipo greenstone belt; (iii) Supergrupo Minas, de idade proterozóica, constituído por rochas metassedimentares (quartzitos, xistos, filitos e formações ferríferas) e (iv) Grupo Itacolomi, igualmente de idade proterozóica, constituído basicamente por quartzitos.

O modelado regional tem sido objeto de estudo desde os trabalhos de Hader \& Chamberlin (1915), para os quais o relevo da região é fruto de sua estrutura e da erosão diferencial, onde os quartzitos e itabiritos constituem o substrato das terras altas, os xistos e filitos compreendem o substrato das terras de altitude mediana e as terras baixas estão moldadas sobre os granito-gnaisses. Espacialmente, as terras altas constituem um conjunto de cristas e superfícies erosivas soerguidas, que possuem uma forma grosseiramente quadrangular (Quadrilátero Ferrífero), formando o entorno das terras baixas, por onde corre o Rio das Velhas, nível de base da região central do Quadrilátero Ferrífero.

Outras considerações semelhantes acerca dessa conformação geomorfológica, controlada pela estrutura (dobras e falhas) e pela erosão diferencial, foram apresentadas em trabalhos posteriores que investigaram o modelado local procurando compreender ciclos de denudação e aplainamento. Dentre estes, destacam-se os de James (1933), De Martone (1940), Freitas (1951), Ab'Saber (1954),
King (1956), Bigarella \& Ab'Saber (1964), Barbosa \& Rodrigues (1965, 1967), Dorr (1969), Maxwell (1972), Lichte (1979), Barbosa (1980) e Varajão (1991). Este último verificou que a quantidade de ciclos denudacionais identificados em cada um dos trabalhos realizados dependia do conceito que cada autor possuía acerca de superfície de aplainamento. Esta consideração colocou em dúvida os estudos que investigaram os ciclos de denudação e aplainamento no Quadrilátero Ferrífero. Deste modo, no que se refere à gênese da paisagem local, as conclusões acerca da erosão diferencial permanecem atualmente como as únicas de caráter consensual. Entretanto, mesmo estas considerações carecem de comprovação científica, ou seja, todos os estudos que interpretaram a ação da erosão diferencial se basearam em análises dedutivas. Sendo assim, não foi realizado nenhum estudo que, com dados de campo e/ou laboratório, comprovasse quantitativamente a atuação deste tipo de erosão. Neste contexto, insere-se o presente trabalho, que procura investigar quantitativamente a existência da erosão diferencial no Quadrilátero Ferrífero e assim verificar a hipótese levantada nas investigações geomorfológicas anteriores. Para tanto, o método utilizado se baseia na análise dos padrões locais de denudação geoquímica (análises hidroquímicas), comparando-as com os litotipos das bacias investigadas, verificando assim se as águas fluviais possuem a assinatura geoquímica dos litotipos que drenam.

\section{Método}

O método adotado baseia-se na coleta das águas fluviais superficiais de quatro sub-bacias hidrográficas que drenam a área em questão e apresentam baixa interferência antrópica, diversidade litoestrutural e paisagens interpretadas como fruto da erosão diferencial (Figura 1): (i) alta Bacia do Córrego de Fechos; (ii) Bacia do Córrego Cata Branca; (iii) alta Bacia do Córrego Maracujá e; (iv) alta Bacia do Ribeirão Caraça. 


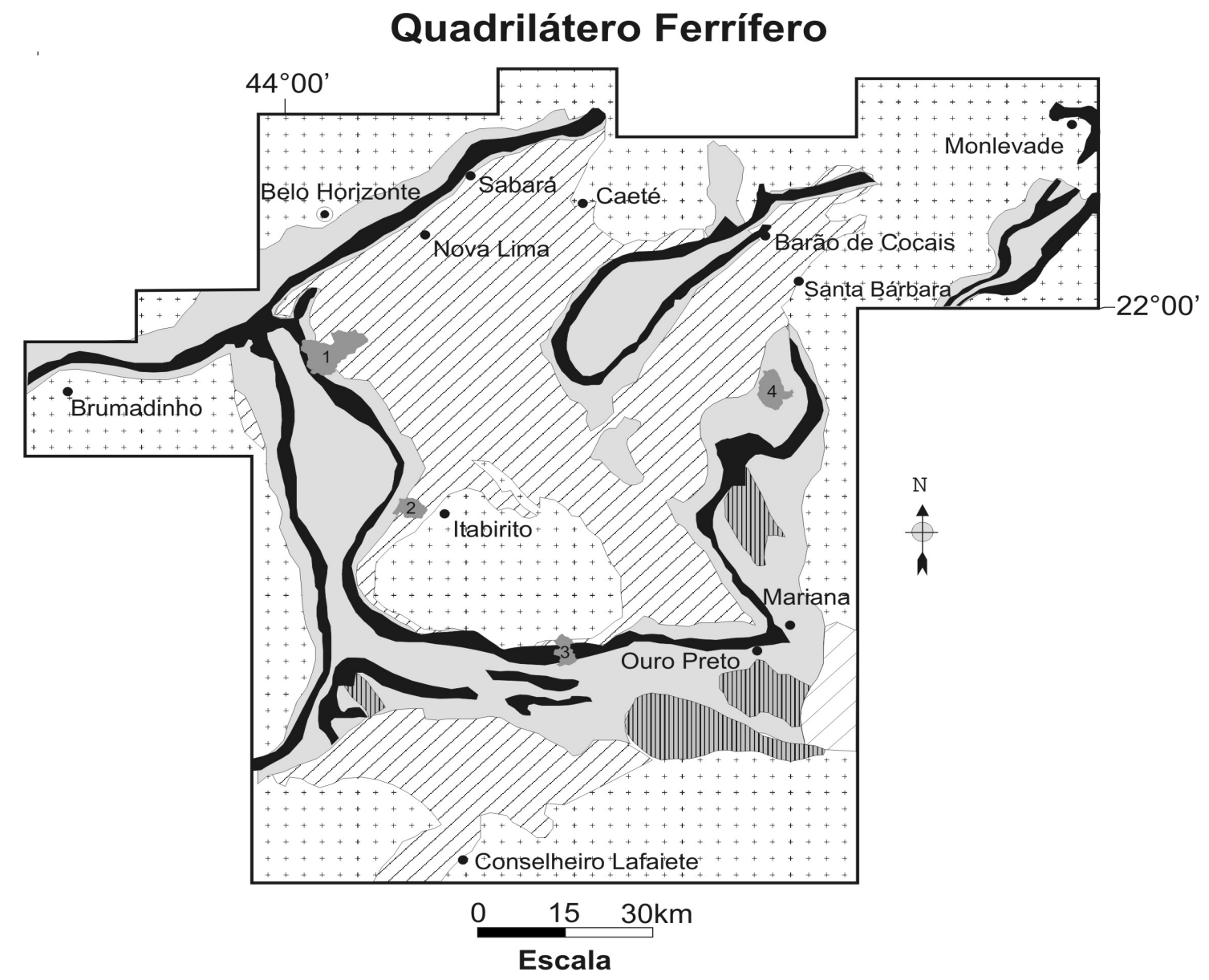

\section{Legenda:}
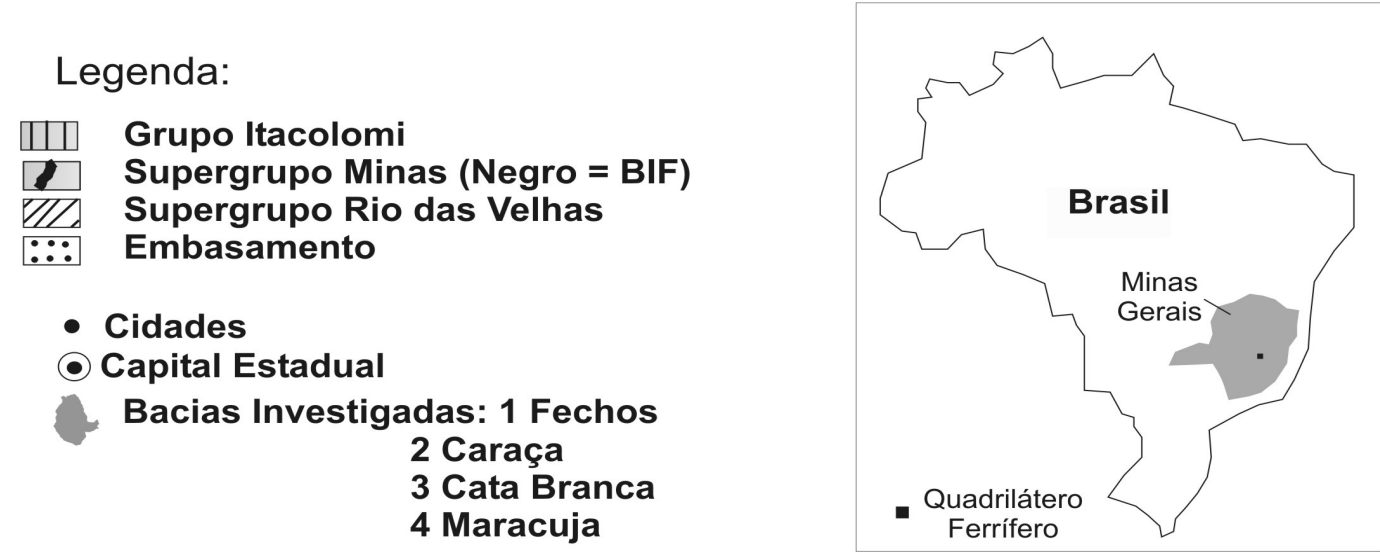

Figura 1 - Geologia do Quadrilátero Ferrífero (Alkmim \& Marshak, 1998).

As amostras foram coletadas em nascentes e em canais fluviais de ordens hierárquicas diversas durante dois períodos distintos do ano: (i) fevereiro de 2003 (final do período úmido) e julho de 2003 (final do período seco). As coletas foram realizadas com auxílio de seringas de $25 \mathrm{ml}$ no meio dos canais fluviais. As águas coletadas foram filtradas com filtros descartáveis Nalgene de 0,45 micrometrômetros e acondicionadas em frascos virgens de $100 \mathrm{ml}$ aos quais, para melhor conservação, acrescentou-se duas gotas de ácido nítrico $\left(\mathrm{HNO}_{3}\right)$ puro. Em todas as amostragens sempre foram coletadas amostras em duplicata. Os elementos $\mathrm{Mn}, \mathrm{Fe}, \mathrm{Mg}, \mathrm{Al}, \mathrm{Si}, \mathrm{Ca}, \mathrm{Na}$ e K presentes nas amostras de água foram analisados, no LGqA - Laboratório de Geoquímica Ambiental do DEGEO/EM/UFOP, via Espectrometria de Emissão Atômica por Plasma (ICP-OES Spectro Cirus CCD). Para validação dos resultados foi utilizado o padrão internacional 
de água NIST (Standard Reference Material NIST 1643d Trace Elements in Water). Já os dados referentes a $\mathrm{pH}$, sólidos totais dissolvidos (TDS) e condutividade foram mensurados em campo com auxílio de equipamento multiparâmetro portátil marca Myron. Paralelamente à coleta das amostras de água foi mensurada a vazão dos cursos fluviais.

Os pontos de coleta em cada bacia visaram amostrar a água que drena um único litotipo de uma determinada sub-bacia e o somatório das contribuições dos litotipos situados à montante. Deste modo, verificou-se o padrão de denudação geoquímica de cada litotipo. Além disso, foram amostradas as águas dos exutórios das bacias e, com isso, foi possível verificar se a taxa de denudação final de cada bacia correspondia à somatória das taxas de denudação de suas subbacias e dos respectivos litotipos.

Os dados referentes aos sólidos totais dissolvidos nas amostras de água foram também utilizados para o cálculo da taxa anual de rebaixamento do relevo para cada litotipo e para cada bacia. O método utilizado para este cálculo encontra-se nos manuais internacionais da literatura geomorfológica como, por exemplo, os de Summerfield (1991), Thomas (1994) e Burbank \& s
Anderson (2001). Esse método propõe que, caso $1 \mathrm{~km}^{2}$ da superfície das áreas continentais perca anualmente uma massa equivalente à densidade de sua rocha constituinte em toneladas, ao final de 1 milhão de anos, essa mesma superfície terá sido rebaixada, verticalmente, em 1 metro. Este método tem por base o cálculo: ((denudação total/ área da bacia)/densidade da rocha de superfície). Para sua realização foram amostradas rochas frescas (furos de sondagem ou em afloramentos) dos litotipos presentes nas bacias investigadas. A densidade de cada amostra de rocha foi calculada com o uso da Balança de Joly no Laboratório de Mineralogia do DEGEO/EM/UFOP. Já as áreas das bacias e sub-bacias investigadas foram calculadas com o uso do Software MicroStation.

\section{As Bacias Investigadas}

A alta bacia do Córrego de Fechos, com 3 pontos monitorados, possui $26,29 \mathrm{~km}^{2}$. Dentre os litotipos presentes destacam-se filitos e quartzitos (Grupo Caraça), itabiritos e dolomitos (Grupo Itabira) e xistos (Grupo Nova Lima) (Figura 2). Já a bacia do Córrego Cata Branca, á)

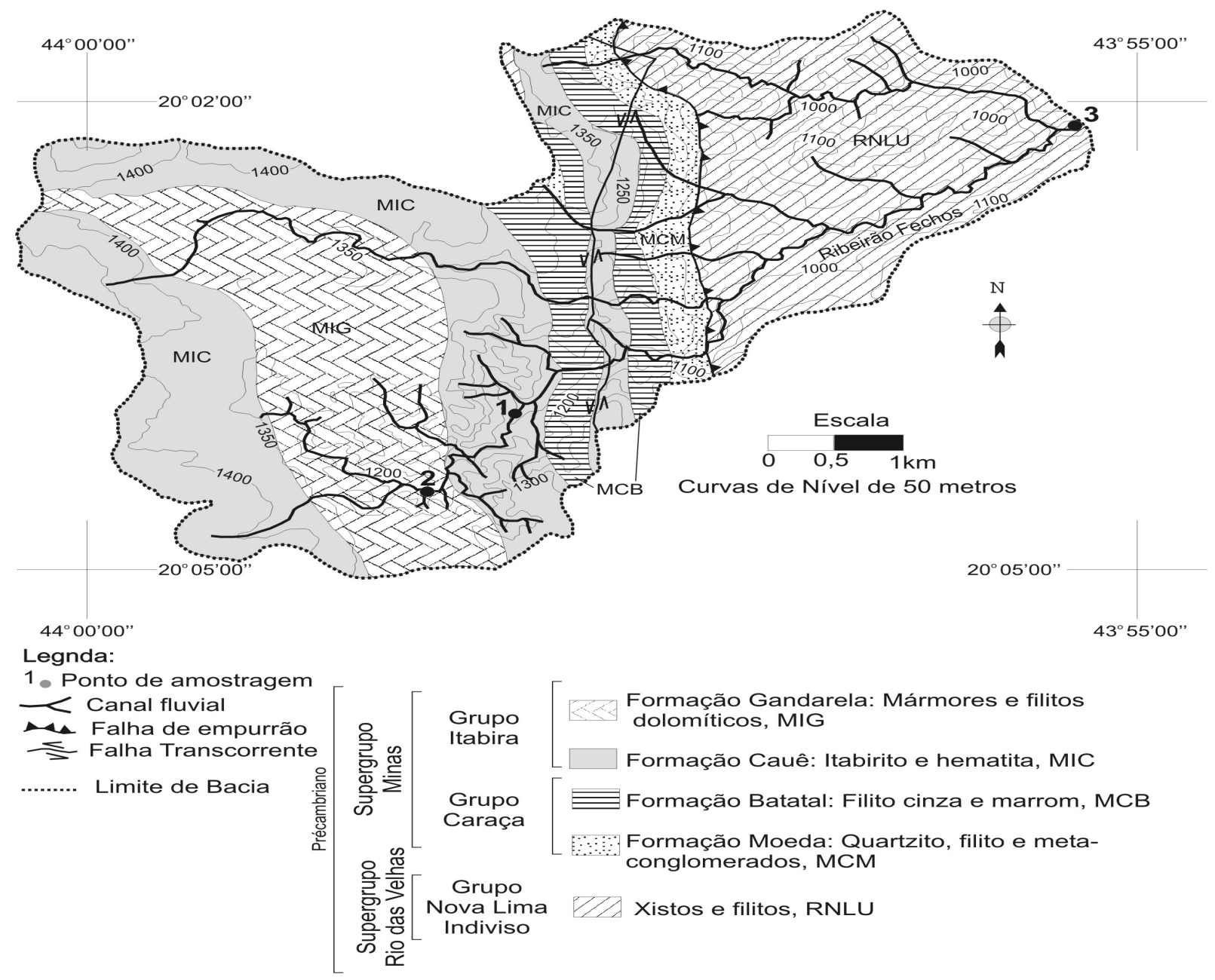

Figura 2 - Geologia da alta Bacia do Córrego Fechos (Pomerene, 1964) 
com área de $15,46 \mathrm{~km} 2$, foi monitorada em 5 pontos e possui litotipos semelhantes aos da alta bacia do Córrego Fechos (Figura 3). A alta bacia do Córrego Maracujá foi monitorada em 5 pontos e possui 15,37 km2. Destacam-se dentre seus litotipos: granitos, gnaisses e migmatitos do embasamento cristalino nas porções menos elevadas da bacia, filitos e quartzitos (Grupo Piracicaba) em sua porção média e xistos (Grupo Sabará) junto às suas cabeceiras (Figura 4). Os quartzitos (Grupo Caraça) e Itabiritos e dolomitos (Grupo Itabira) têm pouca expressão em área. Por fím, a alta bacia do Ribeirão Caraça, monitorada em 4 pontos e com $20,29 \mathrm{~km} 2$, está toda localizada em um compartimento bastante elevado, tendo por substrato quartzitos (Grupo Tamanduá) recortados por diques máficos (Figura 5).

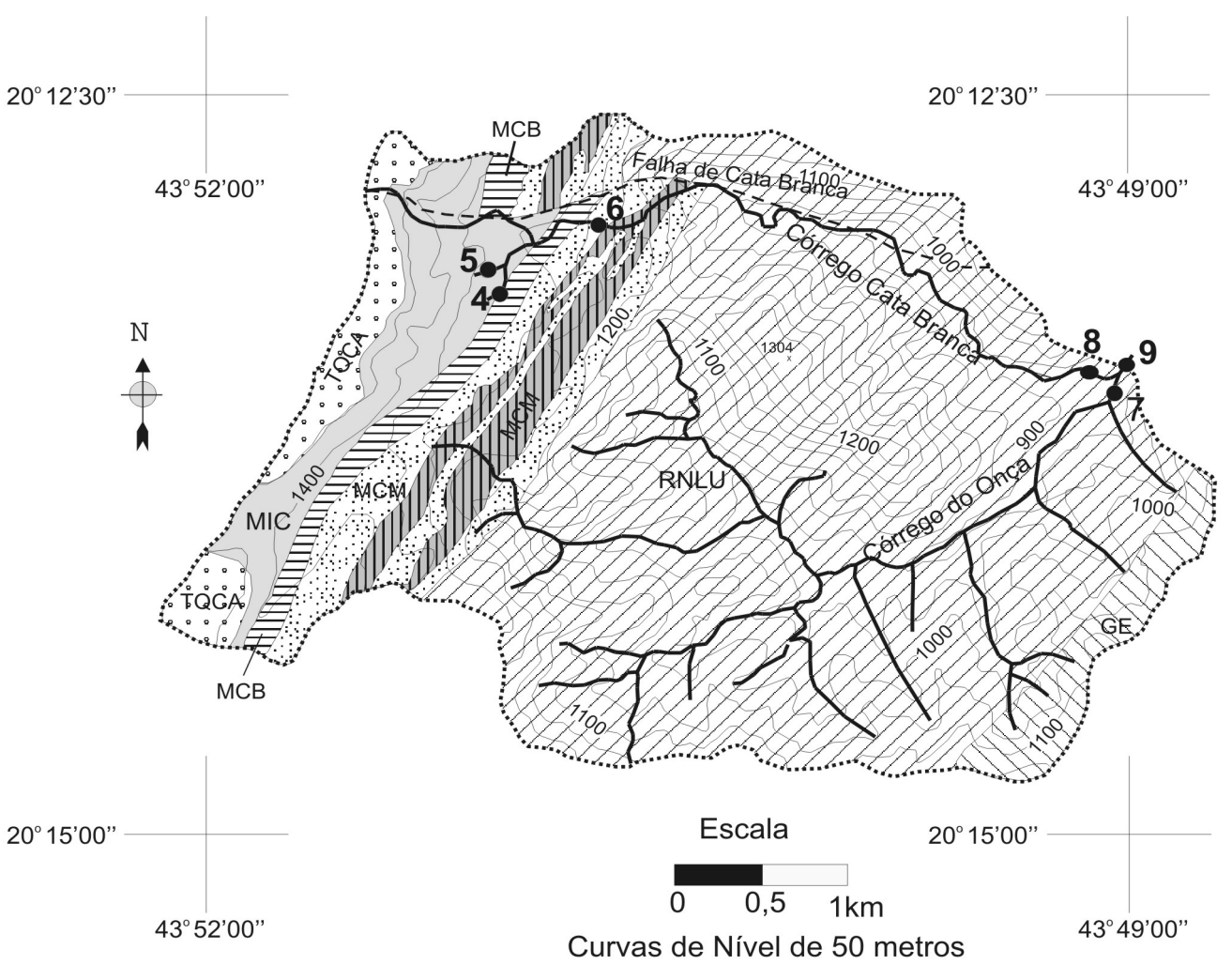

Legenda:

5. Ponto de amostragem

$<$ Canal fluvial

. . . Falha de Cata Branca

Limite de Bacia

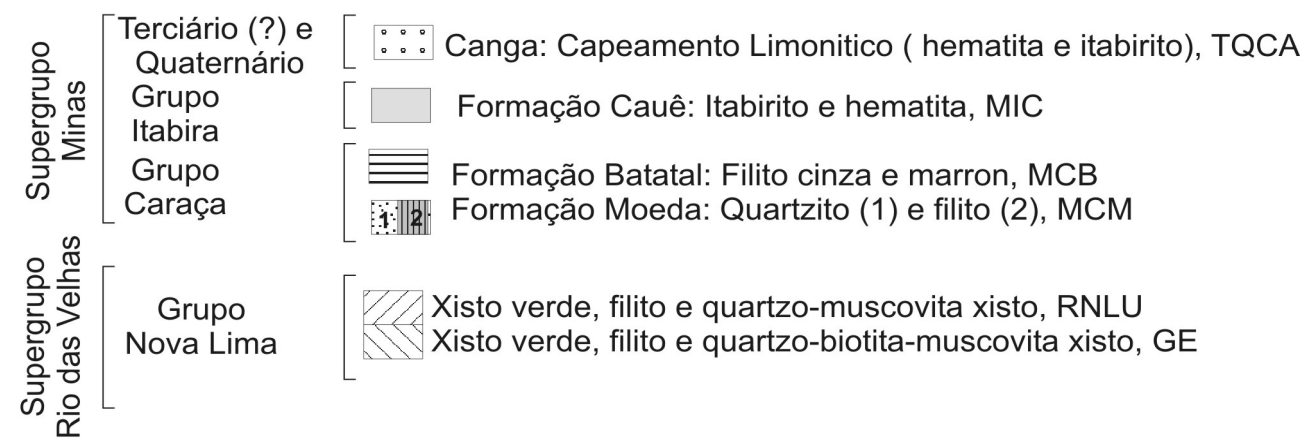

Figura 3- Geologia da Bacia dos Córregos Esperança/Cata Branca (Wallace, 1965) 


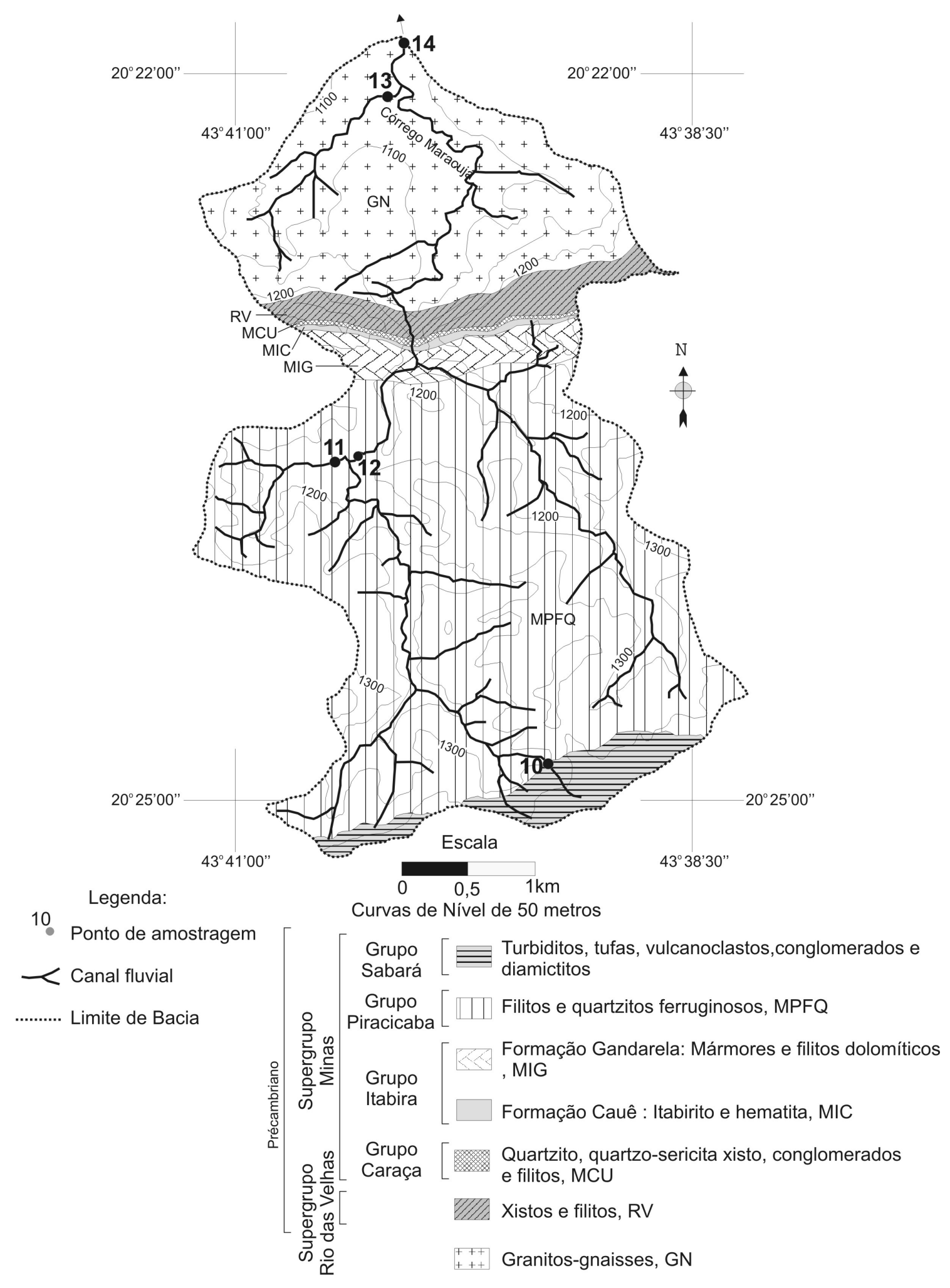

Figura 4 - Geologia da alta Bacia do Córrego Maracujá (Johnson, 1962) 


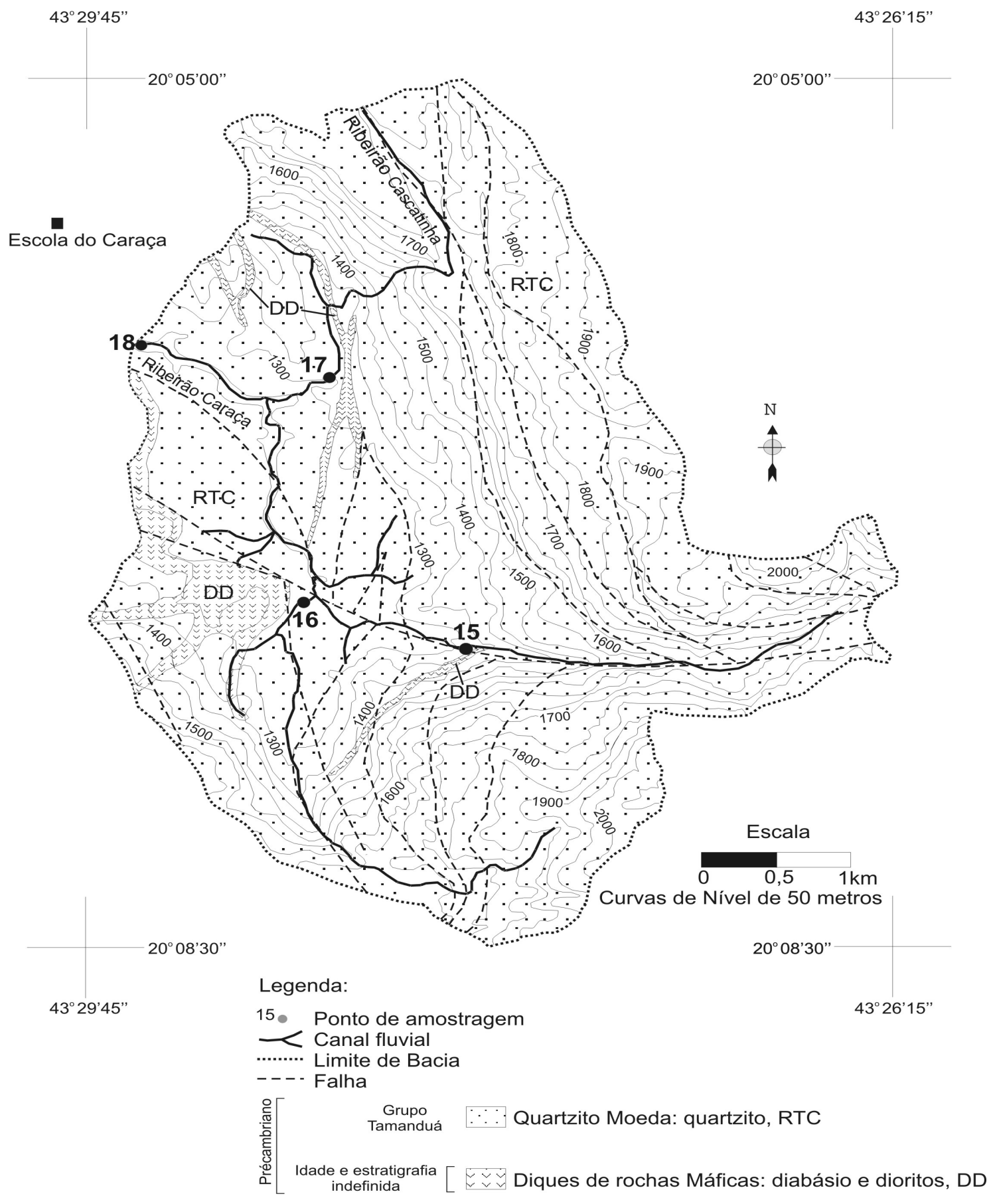

Figura 5 - Geologia da alta Bacia do Ribeirão do Caraça (Maxwell, 1972)

\section{Apresentação dos Resultados}

Os resultados obtidos são apresentados por bacia hidrográfica, sazonalmente e de acordo com $\mathrm{o}(\mathrm{s})$ litotipo(s) à montante dos pontos monitorados (Tabela 1). São apresentadas também as médias anuais de denudação por $\mathrm{km}^{2}$ para cada um dos oito elementos monitorados ( $\mathrm{Ca}, \mathrm{Na}, \mathrm{K}, \mathrm{Fe}, \mathrm{Mg}, \mathrm{Al}$, Mn e
$\mathrm{Si}$ ) e para o total de sólidos dissolvidos em cada bacia, juntamente com suas respectivas subbacias (Tabela 2).

Os resultados anuais de $\mathrm{pH}$ apresentam tendência à acidez - pH entre 4,41 até 6,83 - nas águas fluviais que drenam quartzitos e Itabiritos (Tabela 1). Por outro lado, as águas que drenam as rochas carbonáticas da Bacia de Fechos (Formação Gandarela/Grupo Itabira) tendem a 
Salgado, A. A. R.; F Colin, F.; Nalini, H. A. Jr.; Braucher, R.;Varajão, A. F. DC.; e Varajão, C. A. C. / Revista Brasileira de Geomorfologia, Ano 5, No 1 (2004) 55-69

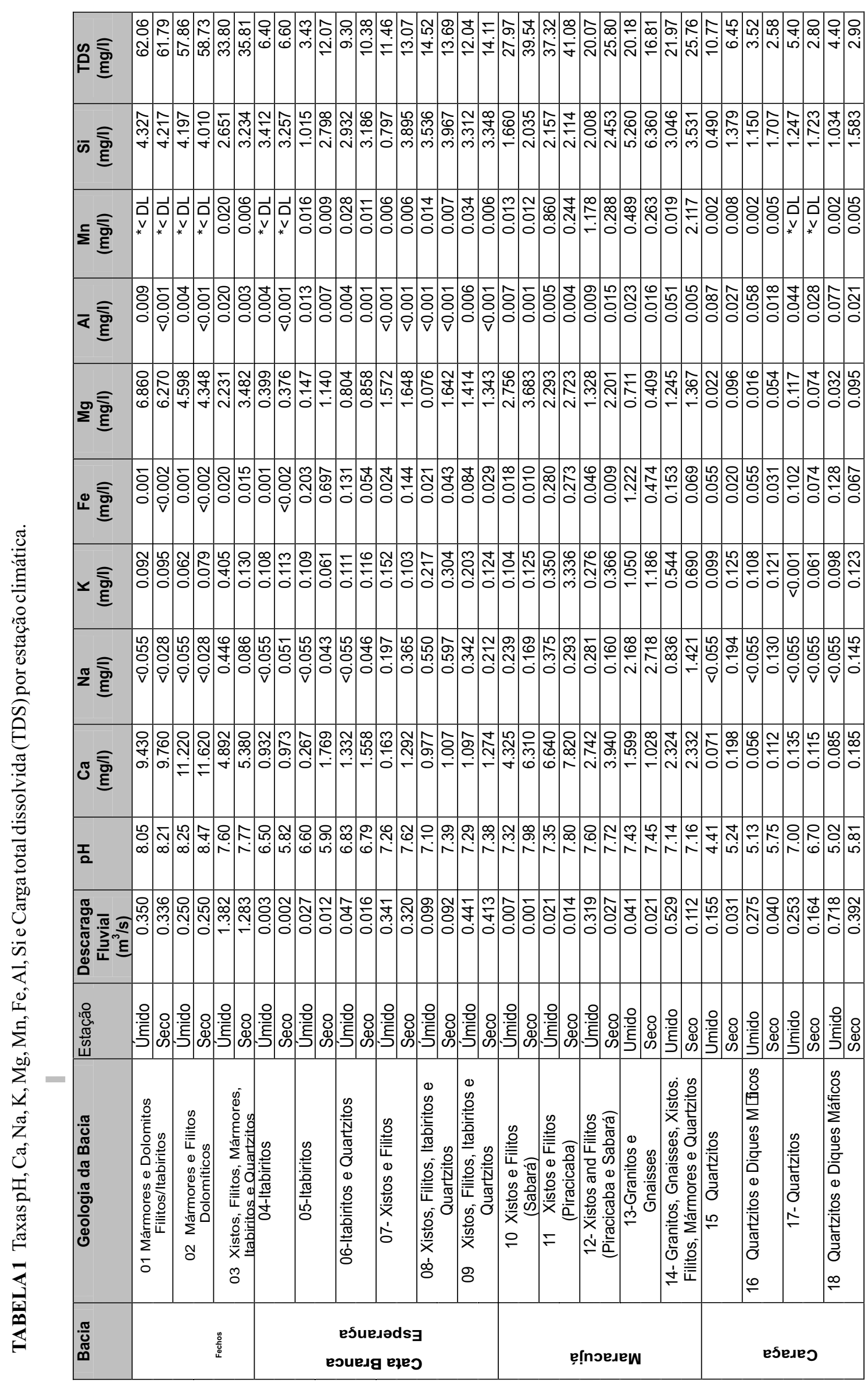




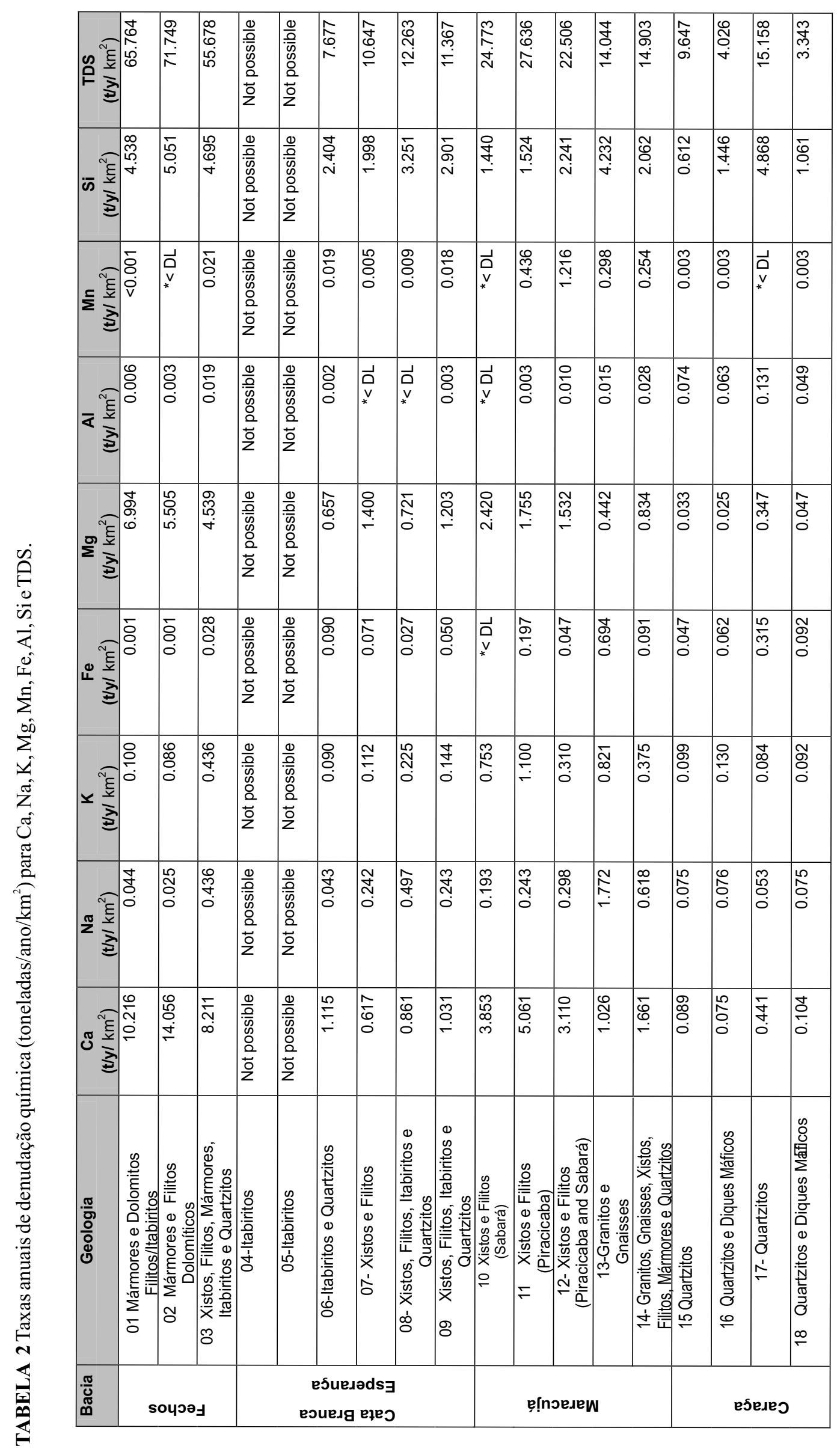


apresentar pH alcalino entre 8,05 e 8,46 (Tabela 1; Figura 2). Nos outros pontos monitorados, principalmente naqueles localizados sobre os xistos e filitos, o pH das águas amostradas tende a ser neutro com leve tendência à alcalinidadade, entre 7,10 e 7,80 (Tabela 1 )

Os valores de lixiviação dos elementos $\mathrm{Ca}$ e $\mathrm{Mg}$ tendem a ser elevados nas rochas carbonáticas sempre superiores a $10,216 \mathrm{ton} / \mathrm{y} / \mathrm{km}^{2}$ para $\mathrm{Ca}$ e à 5,505 ton $/ \mathrm{y} / \mathrm{km}^{2}$ para o $\mathrm{Mg}$; médios sobre os xistos, filitos e gnaisses entre 1,026 e 5,061 ton $/ \mathrm{y} / \mathrm{km}^{2}$ para $\mathrm{Ca}$ e 0,442 e 2,420 ton $/ \mathrm{y} / \mathrm{km}^{2}$ para o $\mathrm{Mg}$; e baixos nos quartzitos e itabiritos sempre inferiores a 1,115 para o Ca e à 0,657 ton $/ \mathrm{y} / \mathrm{km}^{2}$ para o $\mathrm{Mg}$ (Tabela 2).

Os elementos $\mathrm{Na}$ e $\mathrm{K}$, de uma maneira geral, apresentam valores de lixiviação homogêneos em todos os litotipos. Estes são levemente mais elevados apenas nas águas que drenam granitognaisses, xistos ou filitos chegam a 1,772 ton $/ \mathrm{y} / \mathrm{km}^{2}$ para o Na e a 1,100 ton/y/km2 para o K (Tabela 2).

$\mathrm{O} \mathrm{Mn}$ apresenta valores de lixiviação heterogêneos. Em áreas de mármores, dolomitos, quartzitos e itabiritos esses valores são muitas vezes inferiores ao limite de detecção $(0,001 \mathrm{mg} / \mathrm{l})$, fato que impede se calcular o total anualmente lixiviado em ton $/ \mathrm{y} / \mathrm{km}^{2}$ (Tabelas 1 e 2 ) porém, são sensivelmente mais elevados sobre os xistos, filitos, granitos e gnaisses.

$\mathrm{O} \mathrm{Fe}$ e o $\mathrm{Al}$, de uma maneira geral, são os elementos menos lixiviados (Tabela 2). $\mathrm{O} F$ apresenta valores mais baixos sobre as rochas carbonáticas 0,001 ton $/ \mathrm{y} / \mathrm{km}^{2}$, médios sobre quartzitos, itabiritos, xistos e filitos entre 0,050 e $0,347 \mathrm{ton} / \mathrm{y} / \mathrm{km} 2$ e altos sobre os granitos e gnaisses 0,694 ton $/ \mathrm{y} / \mathrm{km} 2$. Já o $\mathrm{Al}$ é homogeneamente lixiviado em todas as rochas, muitas vezes em quantidades inferiores ao limite de detecção, à exceção dos quartzitos, onde geralmente essas taxas superam os 0,047 ton $/ \mathrm{y} / \mathrm{km} 2$ (Tabela 2).

Quanto à silica, esta é, em comparação aos outros elementos, razoavelmente bem lixiviada quase sempre com resultados superiores a 1,000 ton $/ \mathrm{y} / \mathrm{km}^{2}$. Seus valores de lixiviação são homogêneos nos diferentes litotipos, sendo ligeiramente mais elevados nas rochas carbonáticas sempre acima de 4,538 ton $/ \mathrm{y} / \mathrm{km} 2$ (Tabela 2).

Os valores de TDS são baixos nos quartzitos e itabiritos entre 3,343 e 15,158 ton $/ \mathrm{y} / \mathrm{km}^{2}$, médios nos granito-gnaisses, xistos e filitos entre 10,647 e $27,636 \mathrm{ton} / \mathrm{y} / \mathrm{km}^{2}$ - e elevados nas rochas carbonáticas acima de 65,764 ton $/ \mathrm{y} / \mathrm{km}^{2}$ (Tabela 2).

\section{Discussão}

$\mathrm{Na}$ área investigada existe um padrão regional de denudação para cada litotipo, ou seja, um mesmo litotipo, independentemente da bacia em que foi monitorado, possui um mesmo comportamento denudacional.

Quanto à sazonalidade, o total lixiviado (concentração do elemento multiplicado pela vazão na estação) no verão (período umido) é quase sempre maior do que no inverno (período seco) (Tabela 3). Isto ocorre pelo fato de que, apesar de no inverno os elementos se encontrarem mais concentrados (Tabela 1), é no verão que, graças à maior vazão dos cursos fluviais, a denudação é mais intensa (Tabela 3 Figura 6). Vale ainda ressaltar que os elementos $\mathrm{Fe}$ e $\mathrm{Al}$ são os únicos que se apresentam mais concentrados no verão que no inverno (Tabela 1). Entretanto, os valores de lixiviação desses elementos são relevantes somente nos quartzitos onde o $\mathrm{pH}$ das águas é em torno de 5 .

\section{Rebaixamento do Relevo}

A compreensão do processo denudacional regional é facilitada através do cálculo de rebaixamento geoquímico do relevo (Tabela 4 e Figura 7). A análise dos resultados comprova a maior resistência dos quartzitos e itabiritos diante dos processos denudacionais geoquímicos. Demonstra ainda a existência de uma denudação diferencial, onde as áreas que têm por substrato rochas carbonáticas são as mais denudadas e as áreas que têm por substrato os xistos, filitos e granito-gnaisses apresentam taxas de denudação medianas.

No entanto, a comparação teórica entre o total denudado em cada bacia e o total lixiviado de cada litotipo que integra esta bacia, multiplicado pela área que este litotipo ocupa no interior da bacia (Tabela 5), demonstra que o litotipo não é a única variável a influenciar no processo denudacional geoquímico do Quadrilátero Ferrífero. Por exemplo, nas bacias do Caraça e do Maracujá, baseando-se no perfil denudacional de cada litotipo mensurado nas sub-bacias e considerando a hipotese de que toda a área dessa bacia que tenha por substrato esse litotipo estará sujeita a mesma agressividade em seu processo denudacional, o somatório da denudação dos litotipos nas sub-bacias é superior ao que é denudado no exutório das mesmas. Tal fato, conforme já verificado em diversos outros trabalhos a exemplo dos de Stallard \& Edmond (1983) e Summerfield \& Hulton (1994), comprova que o litotipo não é o único fator responsável pela denudação geoquímica. O tectonismo, a erosão mecânica, a topografia, o relevo, o tipo de solo e a própria estrutura, também são variáveis importantes no perfil denudacional de uma região. Sendo assim, um mesmo litotipo, em uma mesma região, pode apresentar comportamento denudacional de intensidade variável. Além disso, diversos trabalhos que investigaram os processos denudacionais em bacias hidrográficas (Stallard et al., 1991; Milliman \& Syvitski, 1992; Anderson et al., 1993; Howard et al., 1994 e Edmond et al., 1995), comprovaram que estes tendem a ser mais agressivos junto às cabeceiras que nas partes baixas dos cursos fluviais. Comprovaram ainda 
Salgado, A. A. R.; F Colin, F.; Nalini, H. A. Jr.; Braucher, R.;Varajão, A. F. DC.; e Varajão, C. A. C. / Revista Brasileira de Geomorfologia, Ano 5, No 1 (2004) 55-69

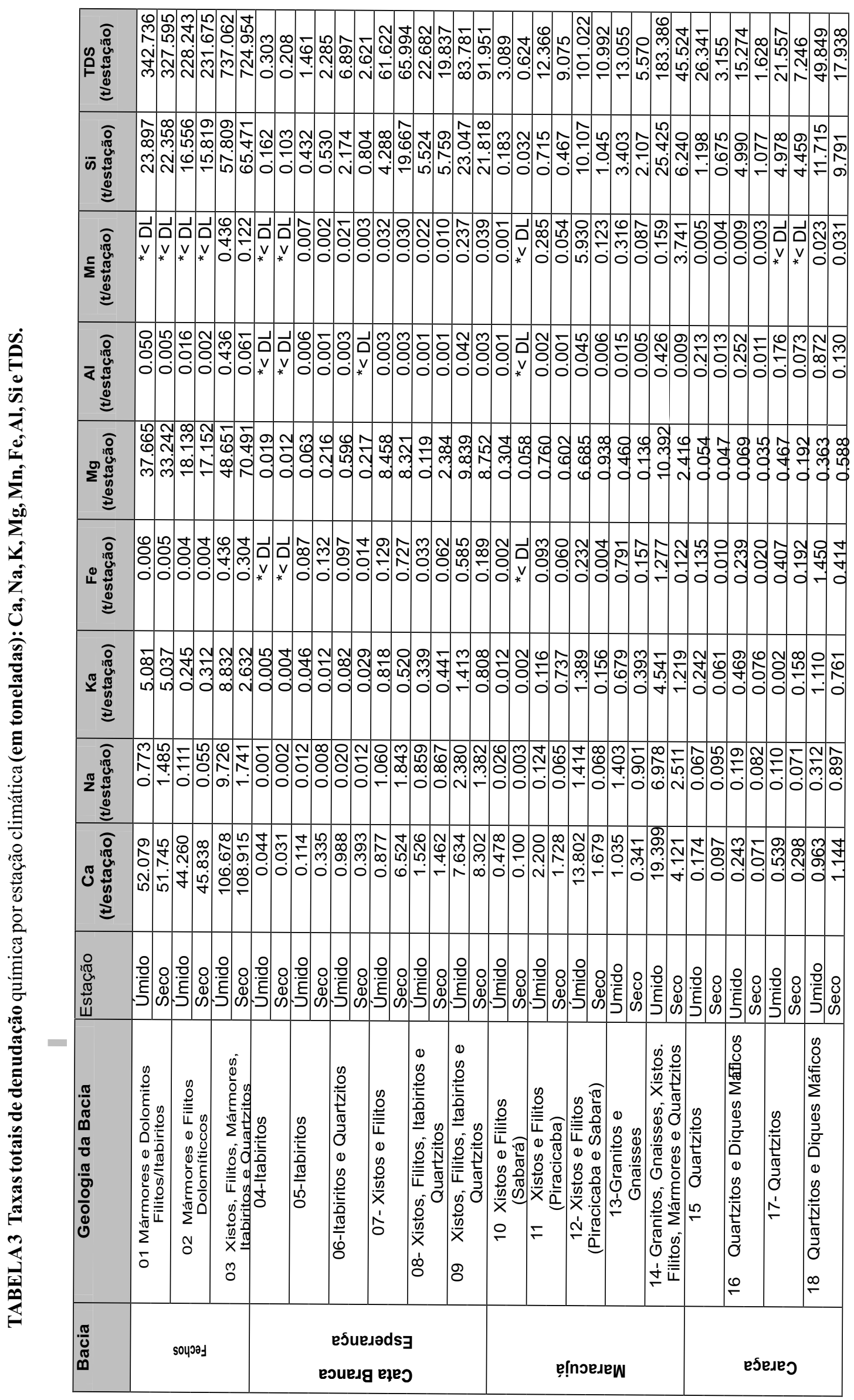




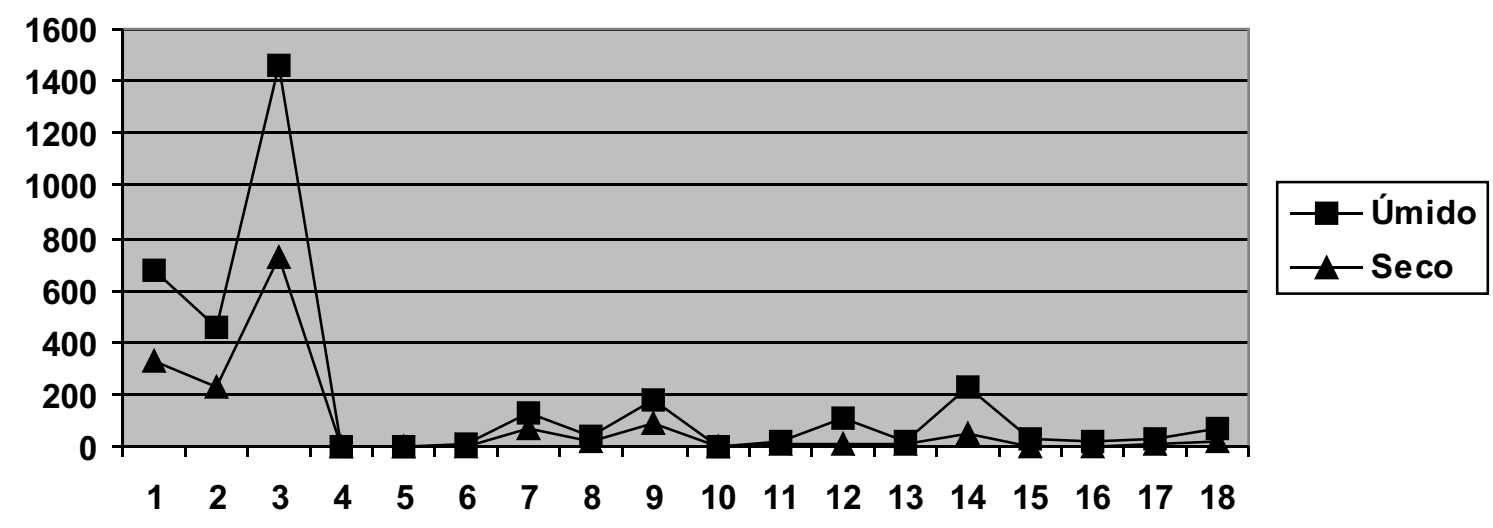

FIGURA6 Taxas totais de denudação química (TDS) em toneladas por estação climática.

TABELA4 Taxas de rebaixamento geoquímico do relevo.

\begin{tabular}{|c|c|c|c|c|c|c|}
\hline Bacia & Pontos & Geologia & $\begin{array}{c}\text { Denudação } \\
\text { Total } \\
\text { (ton) }\end{array}$ & $\begin{array}{c}\text { Densidade } \\
\text { da Rocha de } \\
\text { superfClie }\end{array}$ & $\begin{array}{l}\text { Area da } \\
\text { Bacia } \\
\left(\mathrm{km}^{2}\right)\end{array}$ & $\begin{array}{l}\text { Rebaixamento } \\
\text { Geoqu } \operatorname{mico} \text { do } \\
\text { relevo }(\mathrm{m} / \mathrm{My})\end{array}$ \\
\hline \multirow{3}{*}{ 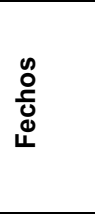 } & 01 & $\begin{array}{c}\text { Mármores e } \\
\text { Dolomitos Filitos/Itabiritos }\end{array}$ & 670.33 & 2.83 & 10.17 & 19.52 \\
\hline & 02 & Mármores e Filitos Dolomítccos & 459.92 & 2.83 & 6.41 & 25.35 \\
\hline & 03 & $\begin{array}{c}\text { Xistos, Filitos, } \\
\text { Mármores, Itabiritos e Quartzitos }\end{array}$ & 1462.02 & 3.02 & 26.29 & 17.18 \\
\hline \multirow{6}{*}{ 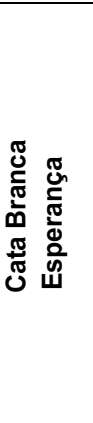 } & 04 & Itabiritos & $\begin{array}{c}\text { Not } \\
\text { possible }\end{array}$ & 3.91 & 0.0 & * \\
\hline & 05 & Itabiritos & $\begin{array}{c}\text { Not } \\
\text { possible }\end{array}$ & 3.91 & 0.0 & * \\
\hline & 06 & $\begin{array}{l}\text { Itabiritos e } \\
\text { Quartzitos }\end{array}$ & 9.52 & 3.24 & 1.24 & 2.37 \\
\hline & 07 & $\begin{array}{l}\text { Xistos e } \\
\text { Filitos }\end{array}$ & 127.66 & 3.02 & 3.99 & 3.53 \\
\hline & 08 & $\begin{array}{l}\text { Xistos, Filitos, } \\
\text { Itabiritos e Quartzitos }\end{array}$ & 42.56 & 3.02 & 11.47 & 3.91 \\
\hline & 09 & $\begin{array}{l}\text { Xistos, Filitos, } \\
\text { Itabiritos e Quartzitos }\end{array}$ & 175.73 & 3.02 & 15.46 & 3.69 \\
\hline \multirow{5}{*}{$\begin{array}{l}\frac{\pi}{3} \\
\frac{0}{\pi} \\
\frac{\pi}{\pi} \\
\Sigma\end{array}$} & 10 & $\begin{array}{l}\text { Xistos e Filitos } \\
\text { (Sabará) }\end{array}$ & 3.71 & 2.84 & 0.15 & 8.71 \\
\hline & 11 & $\begin{array}{l}\text { Xistos e Filitos } \\
\text { (Piracicaba) }\end{array}$ & 21.44 & 2.81 & 0.88 & 9.84 \\
\hline & 12 & $\begin{array}{c}\text { Xistos e Filitos } \\
\text { (Piracicaba e Sabará) }\end{array}$ & 112.01 & 2.81 & 4.98 & 8.01 \\
\hline & 13 & $\begin{array}{l}\text { Granitos e } \\
\text { Gnaisses }\end{array}$ & 18.63 & 2.73 & 1.15 & 5.14 \\
\hline & 14 & $\begin{array}{l}\text { Granitos, Gnaisses, Xistos, } \\
\text { Filitos, Mármores e Quartzitos }\end{array}$ & 228.91 & 2.73 & 15.37 & 5.48 \\
\hline \multirow{4}{*}{ 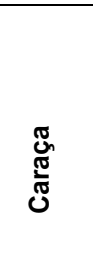 } & 15 & Quartzitos & 29.50 & 2.57 & 3.06 & 3.75 \\
\hline & 16 & Quartzitos e Diques Máficos & 16.90 & 2.57 & 4.20 & 1.57 \\
\hline & 17 & Quartzitos & 28.80 & 2.57 & 1.90 & 5.90 \\
\hline & 18 & Quartzitos e Diques Máficos & 67.79 & 2.57 & 20.29 & 1.30 \\
\hline
\end{tabular}


Salgado, A. A. R.; F Colin, F.; Nalini, H. A. Jr.; Braucher, R.;Varajão, A. F. DC.; e Varajão, C. A. C. / Revista Brasileira de Geomorfologia, Ano 5, № 1 (2004) 55-69

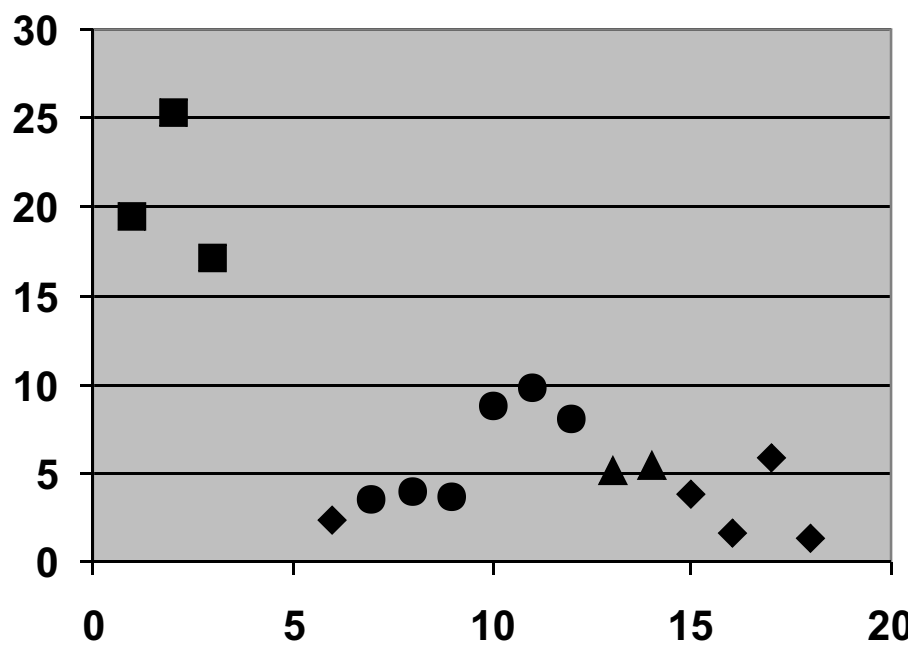

\section{Itabiritos e quartzitos Rochas carbonaticas $\Delta$ Granitos e gnaisses OXistos e Filitos}

Figura 7 - Taxas de rebaixamento geoquímico do relevo por litotipos (m/Ma).

TABELA 5 - Relação entre a denudação total nas bacias hidrográficas com as médias de denudação de cada litotipo.

\begin{tabular}{|c|c|c|c|c|c|}
\hline Bacia & Geologia & $\begin{array}{c}\text { Area do } \\
\text { Litotipo na } \\
\text { Bacia } \\
\left(\mathrm{km}^{2}\right)\end{array}$ & $\begin{array}{c}\text { Média de } \\
\text { denudação do } \\
\text { litotipo } \\
\left(\mathrm{t} / \mathrm{km}^{2}\right)\end{array}$ & $\begin{array}{c}\text { Total de } \\
\text { denudação do } \\
\text { litotipo } \\
\text { (Ton) }\end{array}$ & $\begin{array}{c}\text { Soma das taxas } \\
\text { de denudação } \\
\text { por litotipos em } \\
\text { relação ao total } \\
\text { denudado no } \\
\text { exutório da } \\
\text { Bacia }\end{array}$ \\
\hline \multirow{6}{*}{ 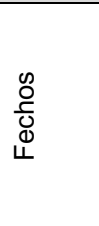 } & Gandarela: Rochas Carbonáticas & 6.082 & 71.75 & 436.4 & \multirow{6}{*}{$44 \%$} \\
\hline & Cauê: Itabiritos e hematitas & 9.235 & 7.53 & 69.5 & \\
\hline & Batatal: Filitos & 2.453 & 22.51 & 55.2 & \\
\hline & Moeda: Quartzitos & 1.271 & 4.03 & 5.1 & \\
\hline & Nova Lima: Xistos e Filitos & 7.248 & 10.65 & 77.2 & \\
\hline & Total da Bacia & 26.288 & 55.68 & 1463.7 & \\
\hline \multirow{7}{*}{ 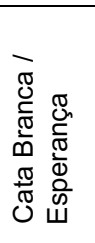 } & Capeamento Limonitico & 0.627 & 7.53 & 4.7 & \multirow{7}{*}{$95 \%$} \\
\hline & Cau周:Itabiritos e hematitas & 1.179 & 7.53 & 8.9 & \\
\hline & Batatal: Filitos & 0.529 & 22.51 & 11.9 & \\
\hline & Moeda: Quartzitos & 1.365 & 4.03 & 5.5 & \\
\hline & Moeda: Filitos & 0.854 & 22.51 & 19.2 & \\
\hline & Nova Lima: Xistos e Filitos & 10.908 & 10.65 & 116.2 & \\
\hline & Total da Bacia & 15.462 & 11.37 & 175.8 & \\
\hline \multirow{8}{*}{$\begin{array}{l}: \frac{\pi}{3} \\
\frac{0}{\pi} \\
\frac{\pi}{\pi} \\
\sum\end{array}$} & Sabará: Xistos e Filitos & 0.684 & 24.77 & 16.9 & \multirow{8}{*}{$162 \%$} \\
\hline & $\begin{array}{c}\text { Piracicaba: Xistos, Filitos e Quartzitos } \\
\text { ferruginosos }\end{array}$ & 9.154 & 27.64 & 253.0 & \\
\hline & Gandarela: Rochas Carbonáticas & 0.559 & 71.75 & 40.1 & \\
\hline & Cauê: Itabiritos e hematitas & 0.089 & 7.53 & 0.7 & \\
\hline & Caraça: Quartzito-Xisto e Filitos & 0.073 & 4.03 & 0.3 & \\
\hline & Caraça: Xistos e Filitos & 0.066 & 22.51 & 1.5 & \\
\hline & Embasamento: Granitos e Gnaisses & 4.150 & 14.04 & 58.3 & \\
\hline & Total da Bacia & 15.368 & 14.90 & 229.0 & \\
\hline \multirow{3}{*}{ 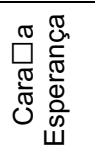 } & Moeda: Quartzitos & 19.211 & 4.03 & 77.4 & \multirow[b]{3}{*}{$121 \%$} \\
\hline & Diques de rochas Máficas & 1.082 & 4.03 & 4.4 & \\
\hline & Total da Bacia & 20.293 & 3.34 & 67.8 & \\
\hline
\end{tabular}


que quanto menor e mais elevada em relação a seu nível de base for uma bacia hidrográfica, mais agressivo será o seu processo denudacional. Logo, os resultados obtidos no presente trabalho encontram-se em acordo com estas constatações, visto que as somatórias teóricas das taxas de denudação mensuradas nos litotipos nas sub-bacias (áreas mais próximas das cabeceiras) tendem a ser superiores ao verificado no exutório da bacia hidrográfica (Tabela 5). Fora isso, a diferença existente entre o somatório de denudação nos litotipos com o total denudado no ponto final da bacia, pode ser ainda explicado pela possibilidade de que parte do material denudado nas cabeceiras tenha sido retido ao longo do canal fluvial pela biota ou pelos solos e, sendo assim, não tenha alcançado o exutório.

A verificação de que o processo denudacional é mais agressivo junto as cabeceiras de drenagem reforça a constatação da existência da denudação diferencial na área investigada. Isto ocorre em função de que os quartzitos e itabiritos, apesar de se localizarem nas superfícies mais elevadas, justamente onde o processo denudacional deveria ser mais agressivo, constituem as litologias menos denudadas no Quadrilátero Ferrífero (Tabela 2; Figura 7).

Quanto à Bacia de Fechos, esta apresenta um comportamento contrário: a somatória do total denudado em cada litotipo é muito inferior ao que realmente está sendo denudado no exutório da bacia (Tabela 5). Isto ocorre em razão de que essa bacia é rica em rochas carbonáticas e se encontra muito falhada, favorecendo assim um intenso fluxo subsuperficial. Este fluxo subsuperficial possui águas que lixiviaram as rochas carbonáticas mas ressurgiram também em áreas de xistos. Sendo assim, no exutório da bacia, estas águas foram computadas como águas que intemperizaram apenas xistos, quando na verdade elas ressurgem nos xistos já enriquecidas por elementos provenientes das rochas carbonáticas. Tal fato explica que no exutório tenha sido mensurada uma denudação extremamente elevada em relação àquela que se poderia esperar com relação à área de superfície que cada litotipo ocupa no interior da bacia (Tabela 5).

$\mathrm{Na}$ Bacia Esperança/Cata Branca, o somatório das taxas de denudação por litotipo é quase igual ao denudado no exutório da bacia $(95 \%)$. Como os itabiritos e quartzitos, que se encontram na cabeceira desta bacia, possuem taxas de denudação pouco significativas, tal fato pode ser explicado em razão de que este cálculo, nesta bacia, é feito, para suas demais rochas, a partir de pontos de monitoramento próximos ao exutório (Figura 3). Logo, é feito a partir de pontos que não apresentam significativas diferenças de área e distância das cabeceiras com relação àqueles encontrados no ponto final da bacia.

Por fim, a explicação para que rochas relativamente susceptíveis à denudação geoquímica ainda se encontrem em superfícies elevadas, a exemplo de rochas carbonáticas, xistos e filitos, pode estar relacionada às observações de Tricart (1961) e Barbosa \& Rodrigues (1967), de que esses litotipos não teriam sido tão resistentes à denudação, mas são sustentados em superfícies elevadas graças à existência de cinturões de quartzitos e itabiritos, que constituem as bordas de sinclinais e anticlinas invertidos topográficamente. Além disso, existe a possibilidade de um tectonismo recente ter soerguido algumas porções do Quadrilátero Ferrífero (Lipski, 2002).

\section{Conclusões}

O presente trabalho verifica que a diferença de altitude em relação ao nível de base, bem como a área da bacia hidrográfica são variáveis que influem na intensidade da denudação geoquímica no Quadrilátero Ferrífero. Além disso, demonstra quantitativamente a existência de uma denudação geoquímica diferencial onde: os quartzitos e Itabiritos constituem as rochas mais resistentes, os xistos, filitos e granito-gnaisses as de resistência mediana e os mármores e dolomitos as de menor resistência. Este fato prova, quantitativamente, que as análises qualitativas presentes nos diversos estudos geomorfológicos já realizados no Quadrilátero Ferrífero, estavam corretas em atestar que o modelado regional possui em sua genêse processos relacionados à erosão diferencial. Por fim, o presente artigo comprova ainda que as águas regionais são capazes de marcar a assinatura geoquímica das litologias que drenam.

\section{Agradecimentos}

Agradecemos à CAPES e à COFECUB (projeto 406/02) pelo financiamento. Agradecemos às Minerações Brasileiras Reunidas (MBR) pelo apoio aos trabalhos de campo e à Mineração Morro Velho pelas amostras de rochas de furos de sonda. Por fim, agradecemos aos colegas do DEGEO/UFOP Guilherme Gravina, Fernando Moraes e ao Cláudio Lana pelo apoio na coleta das amostras de água. E, em especial, a Janice Cardoso Pereira e Adriana Trópia Guimarães pela análise das amostras de água no ICP-AES do Laboratório de Geoquímica Ambiental do DEGEO/UFOP.

\section{Referências Bibliográficas}

Ab' Saber, A. N. (1954) As altas Superfícies de Aplainamento do Brasil Sudeste. Campinas: Ver. Fac. Campineiras, 1(4): 60-67.

Alkmim F. F. \& Marshak S. (1998) Transamazonian Orogeny in the Southern São Francisco Craton Region, Minas Gerais, Brazil: evidence for Peleoproterozoic 
collision and collapse in the Quadilátero Ferrífero. Precambrian Research 90; p:29-98.

Almeida, F. F. M. (1977) O Cráton do São Francisco. São Paulo: Revista Brasileira de Geociências. 7(4): 349-364.

Anderson, S. P; Dietrich, W. E; Torres, R; Montgomery, D. R. \& Loague, K. (1993) A case for geochemical control of concentrationdischarge relationships. Chemical Geology; 107: 369-371.

Barbosa G. V. (1980) Superfícies de Erosão no Quadrilátero Ferrífero. São Paulo. Revista Brasileira de Geociências, 10 (1): 89-101.

Barbosa G. V. \& Rodrigues D. M. S. (1965) O Quadrilátero Ferrífero e seus problemas Geomorfológicos. Belo Horizonte: Bol. Min. Geografia, 10/11:3-35.

Barbosa G. V. \& Rodrigues D. M. S. (1967) Quadrilátero Ferrífero. Belo Horizonte, IGC/UFMG. 130pp.

Bigarella, J. J. \& Ab' Saber, A. N. (1964) Paläogeographische und paläoklimatische Aspekte des Känozoikums in Südbrasilien. Stuttgart: Z. Geomorph. N. F., 8(3): 286-312.

Burbank D. W. \& Anderson R. S. (2001) Tectonic Geomorphology. London. Blacwell Science. $274 p$.

De Martone, E. (1940) Problèmes Morphologiques du Brésil Tropical Atlantique. Annales de Géographie. I(XIV-XVI): 1-27; 126-129.

Dorr, J. V. N. (1969) Physiographic, stratigraphic and structural development of the Quadrilátero Ferrífero, Minas Gerais, Brazil. Washington US Geol Surv Prof Pap 110 p. 641-A

Edmond, J. M; Palmer, M. R; Measures, C. I; Grant, B. \& Stallard, R. F. (1995) The fluvial geochemistry and denudation rate of the Guayana Shhield in Venezuela, Colombia, and Brazil. Geochimica et Cosmochimica Acta, Vol. 59, N 16. P:3.301-3.325.

Freitas, R. O. (1951) Relevos policíclicos na tectônica do Escudo Brasileiro. Bol. Paulista Geografia, 7:3-19.

Hader, E. C. \& Chamberlin, R. T. (1915) The Geology of Central Minas Gerais. J. Geol. 23 (445): 341-424.

Howard, A. D; Dietrich, W. E. \& Seidl, M. A. (1994) Modeling fluvial erosion on regional to continental scales. Jounal of Geophysical Research, Vol. 99, NB7. P:13.971-13.986.

James, P. (1933) The surfaces configuration of the southearsten Bazil. Ann. Ass. America Geogr., 23 (3): 165-193.

Johnson R. F. (1962) Geology and ore depositis of the Cachoeira do Campo and Ouro Branco Quadrangles, Minas Gerais, Brazil US Geol Surv Prof Paper 37p. 341-B

King C. L. (1956) A Geomorfologia do Brasil Oriental. Revista Brasileira de Geociências 18 (2) (1956) 147-265.

Lichte, M. (1979) Morphologie Untersuchung in der Serra do Caraça und ihrem Vorland. Göttigen. 139p. Diss, Universität zu Göttigen.
Lipski, M. (2002) Tectonismo cenozóico no Quadrilátero Ferrífero, Minas Gerais. Ouro Preto. 171p. Diss, DEGEO/EM/Universidade Federal de Ouro Preto.

Maxwell, C. H. (1972) Geology and ore deposits of the Alegria district, Minas Gerais, Brazil. Washington, U.S. Geol. Survey Prof. Paper. 72pp. (341j).

Milliman, J. D. \& Syvitski, J. P. M. (1992) Geomorphic/Tectonic Control of Sediment Discharge to the Ocean: The Importance of Small Mountainous Rivers. The Journal of Geology. Chicago, V100: 525-544.

Pomerene, J. B. 1964. Geology and ore depositis of the Belo Horizonte, Ibirité and Macacos Quadrangles, Minas Gerais, Brazil US Geol Surv Prof Paper 84 p. 341-D

Stallard, R. F. \& Edmond, J. F. (1983) Geochemistry of the Amazon The Influence of geology and weathering environment on the dissolved load. Jounal of Geophysical Research, Vol. 88, N 14. P: 9.671-9.688.

Stallard, R. F; Koehnken, L. \& Johnsson, M. J. (1991) Weathering processes and the composition of inorganic material transported through the Orinoco River system, Venezuela and Colombia. Geoderma, 51. P: 133-165.

Summerfield, M. A. (1991) Global Geomorphology: an introduction of the study of landforms. Longman Scientific \& Technical, 129-144, 163-203, 371-395, 457478.

Summerfield, M. A. \& Hulton, N. J. (1994) Natural Controls of fluvial denudation rates in major world drainage basins. Journal of Geophysical Research. Vol. 99, N B7. P:13.871-13.883.

Thomas, M. F. (1994) Geomorphology in the tropics: a study of weathering and denudation in low latitudes. John Wiley \& Sons Ltd., $460 \mathrm{p}$.

Tricart, J. (1961) O Modelado do Quadrilátero Ferrífero Sul de Belo Horizonte. Annales de Geographie. Ano 70, N 379. P: 255-272.

Varajao, C. A. C. (1991) A questão da correlação das superfícies de erosão do Quadrilátero Ferrífero, Minas Gerais. São Paulo: Revista Brasileira de Geociências. 21(2): 138-145.

Wallace R.M. (1965) Geology and mineral resources of the Pico de Itabirito District, Minas Gerais, Brazil US Geol Surv Prof Paper 66 p. 341-F 